\title{
Nasionalisme dan Kewarganegaraan
}

\author{
Winda Roselina Effendi \\ Prodi Ilmu Pemerintahan Fakultas Ilmu Sosial dan Ilmu Politik \\ Universitas Riau Kepulauan, Batam Indonesia \\ winda.effendis@gmail.com
}

\begin{abstract}
According to Mouffe identity is not fixed, based on the concept of democracy that is not a fixed price. This statement refers to Mouffe's statement that there is no absolute and final identity. Mouffe also mentions that discursive discontinuity proceeds unceasingly when speaking of a man or woman of identity only temporarily as long as no new identity has been established by the continuity. thus identity as woman and man is not absolute. It can be said that identity is a distinguishing marker of one group from another group. Isin and Wood in Nuri Suseno asserted that while citizenship proponents generally argue that citizenship is a universal concept, the fact that citizenship is always a group concept. This concept has never been extended to all members of society in a political community. until now there are still many people, in even the most democratic countries, who are not recognized or do not accept citizenship even though they are born in the State.With regard to multinational nations such as Indonesia's wealth, Mouffe seems to be the solution to the heterogeneity and plurality of this nation, not only the majority but inhabited by the vast majority of minority groups. Related to the condition of Inodnesia collected by many minority groups, I agree with Mouffe's citizenship opinion that minority citizens are not something to be negated and hegemonized, but are entities of the national group from the part of the national political development process.
\end{abstract}

Keywords: citizenship, citizenship, identity

\begin{abstract}
Abstrak
Menurut Mouffe identitas tidaklah tetap ini, dilandasi oleh konsep demokrasi yang bukan harga mati. Pernyataan ini mengacu pada pernyataan Mouffe bahwa tidak adanya identitas yang absolut dan final. Mouffe juga menyebutkan bahwa adanya diskursivitas yang berproses tanpa henti, ketika bicara laki-laki atau perempuan identitas tersebut hanya berlaku sementara selama belum ada identitas baru yang dibentuk oleh kesinambungan tadi. dengan demikian identitas sebagai perempuan dan laki-laki tersebut tidaklah mutlak.Dapat dikatakan identitas merupakan penanda pembeda satu kelompok dari kelompok lain. Isin dan Wood dalam Nuri Suseno menegaskan bahwa meskipun umumnya proponen kewarganegaraan mengatakan bahwa kewarganegaraan merupakan sebuah konsep yang universal, faktanya kewarganegaraan selalu merupakan konsep kelompok. Konsep ini tidak pernah diperluas ke seluruh anggota masyarakat dalam sebuah komunitas politik. sampai sekarang masih banyak orang-orang, dalam negara yang paling demokratis sekalipun, yang tidak diakui atau tidak menerima status kewarganegaraan meskipun dilahirkan di Negara.Berkaitan dengan negara multinasional seperti yang menjadi kekayaan Indonesia, Mouffe sepertinya dapat dijadikan solusi atas heterogenitas dan pluralitas bangsa ini, tidak saja kelompok mayoritas tetapi dihuni oleh banyaknya ragam kelompok minoritas. Brkaitan dengan kondisi Inodnesia yang dihimpun oleh banyaknya kelompok minoritas, Saya setuju dengan pendapat kewarganegaraan Mouffe bahwa warganegara yang minoritas bukan sesuatu yang harus dinegasikan dan dihegemoni, tetapi merupakan entitas kelompok bangsa dari bagian proses pembangunan politik nasional.
\end{abstract}

Kata Kunci : warganegara, kewarganegaraan, identitas

\section{PENDAHULUAN}


Memahami konsepsi dan praktek kewarganegaraan, harus dikaitkan dengan pemahaman tentang konsepsi dan identitas. Menurut Mouffe identitas tidaklah tetap ini, dilandasi oleh konsep demokrasi yang bukan harga mati. Pernyataan ini mengacu pada pernyataan Mouffe bahwa tidak adanya identitas yang absolut dan final ( the unfixed of all identities). ${ }^{1}$ Sederhannanya, dalam demokrasi dan identitas menerima nilai-nilai plural, demokrasi bukan konsep universal, melainkan dibentuk oleh nilai-nilai lokal dan particular.

Mouffe juga menyebutkan bahwa adanya diskursivitas yang berproses tanpa henti, ketika bicara laki-laki atau perempuan identitas tersebut hanya berlaku sementara selama belum ada identitas baru yang dibentuk oleh kesinambungan tadi. dengan demikian identitas sebagai perempuan dan laki-laki tersebut tidaklah mutlak. demikianpun dalam negara yang berdemokrasi, warganegara sebagai floating signifier tidak bersifat mutlak dan final. Demokrasi selalu membuka untuk identifikasi baru. ${ }^{2}$ Untuk mengetahui kenapa Mouffe menolak kewarganegaraan cuma 'satu identitas di antara banyak identitas' atau 'satu identitas yang dominan yang menekankan semua identitas lainya', maka berikut penjelasan kewarganegaraan liberal dan kewarganegaraan republican.

\section{TRADISI LIBERAL; KEWARGANEGARAAN SEBAGAI SALAH SATU IDENTITAS DI ANTARA BANYAK IDENTITAS}

Rujukan utama dalam tradisi liberal adalah gagasan-gagasan yang dituliskan oleh T.H. Marshall dalam "Citizenship and Social Class" yang memfokuskan diri pada isu dan masalah kewarganegaraan. Pertama, kewarganegaraan merupakan status yang dinisbatkan/ diberikan/ dianugerahkan oleh suatu komunitas politik dalam hal ini negara kepada warga yang menjadi anggota. Kedua, status itu adalah seperangkat hak dasar yang mencakup hak sipil, politik dan sosial. Hak sipil berkaitan dengan aturan hukum dan kebebasan berbicara; hak politik berkaitan dengan proses politik legal formal terutama hak dipilih/memilih; serta sosial berisikan hak untuk mendapatkan jaminan keamanan dan kesejahteraan yang layak sebagai sesama warganegara. Dengan demikian kewarganegaraan mengimplikasikan kesederajaran secara legal formal.Tiga elemen inilah yang menciptakan status kewarganegaraan.

Nuri Suseno menarik kesimpulan dari gagasan Marshall tersebut bahwa kewarganegaraan merupakan sebuah instrumen sosial politik untuk menyamakan derajad

\footnotetext{
${ }^{1}$ Chantal Mouffe, 2000, The Democratic Paradox, Verso Landon : New York hal 36

${ }^{2}$ Boni hargens, 2006, demokrasi radikal : memahami paradox demokrasi modern dalam perspektif postmarxisostmodernis ernesto laclau dan chantal moufee. LKis : Yogyakarta hal 42
} 
semua anggota komunitas politik yang berasal dari kelas-kelas yang berbeda, tetapi sekaligus merupakan arsitek kemunculan sebuah ketidaksamaan yang baru. ${ }^{3}$

Pengertian tersebut kemudian mengalami perdebatan intelektual seiring dengan perkembangan perpolitikan di level praksis seperti runtuhnya Uni Soviet dan Sosialisme, yang mendesak para ilmuwan untuk merevisi konsepsi yang berkaitan dengan isu kewarganegaraan dan memberi solusi atas munculnya politik identitas yang mengisi ruang kosong pasca hilangnya sosialisme. Hal tersebut sebagaimana diamati oleh Seyla Benhabib yang melihat kemunculan berbagai kelompok identitas kebudayaan tertentu sebagai kontestan dalam debat-debat di wilayah publik dalam sistem demokrasi kapitalis yang memperjuangkan isu redistribusi, pengakuan, dan representasi. ${ }^{4}$ Dan ditegaskan juga oleh Iris M. Young yang melihat pentingnya kelompok dalam menganalisis fenomena perpolitikan akhir-akhir ini yang didefinisikannya sebagai sekumpulan orang-orang yang dapat dibedakan dari minimal satu kelompok lain karena bentuk-bentuk kebudayaan, praktek-praktek atau cara hidup sebagai sebuah sense of identity. ${ }^{5}$

Keterkaitan antara kewarganegaraan dan identitas dalam konteks ini seperti yang dinyatakan dalam pandangan tradisi liberal bahwa kewarganegaraan hanya satu identitas di antara banyak identitas. Pandangan ini secara eksplisit juga diutarakan oleh Charles Tilly dimana menurutnya identitas dapat merujuk pada sebuah kategori, ikatan, peran atau sebuah identitas. Menurutnya, Sebagai identitas, kewarganegaraan merujuk pada pengalaman dan representasi publik dari kategori, ikatan atau peranan. Dengan demikian menurut Tilly, cara pandang klasik dari Marshall tentang kewarganegaraan mengidentifikasikan kewarganegaraan sebagai sebuah seperangkat hak-hak -semacam ikatan khusus dengan kewajiban untuk melaksanakannya-yang mengkaitkan kata kewarganegaraan sebuah negara dengan keseluruhan kategori orang-orang. ${ }^{6}$

Maka, dapat dikatakan identitas merupakan penanda pembeda satu kelompok dari kelompok lain. Isin dan Wood dalam Nuri Suseno menegaskan bahwa meskipun umumnya proponen kewarganegaraan mengatakan bahwa kewarganegaraan merupakan sebuah konsep yang universal, faktanya kewarganegaraan selalu merupakan konsep kelompok. Konsep ini tidak pernah diperluas ke seluruh anggota masyarakat dalam sebuah komunitas politik. sampai sekarang masih banyak orang-orang, dalam negara yang paling demokratis sekalipun,

\footnotetext{
${ }^{3}$ Nuri Suseno, Kewarganegaraan : Tafsir, Tradisi, dan Isu-Isu Kontemporer. Depok : Departemen Ilmu Politik FISIP UI, 2010, hal. 41.

${ }^{4}$ Seyla Benhabib dalam Ibid., hal. 66.

${ }^{5}$ Iris M. Young dalam Ibid., hal. 74-75.

${ }^{6}$ Charles Tilly dalam Ibid., hal. 86.
} 
yang tidak diakui atau tidak menerima status kewarganegaraan meskipun dilahirkan di negara tersebut. Selain itu banyak anggota komunitas politik yang dieksklusikan dari jangkauan kewarganegaraan meskipun secara legal berhak menerima hak-hak. ${ }^{7}$

Dengan demikian, sejumlah penulis kewarganegaraan menyetujui bahwa konsep kewarganegaraan dan identitas tidak boleh dikombinasikan menjadi satu atau sebagai satu hal, tetapi keduanya juga tidak perlu dilihat sebagai dua hal yang bertentangan.

\section{TRADISI REPUBLIKAN; KEWARGANEGARAAN SEBAGAI SATU IDENTITAS DOMINAN YANG MENEKAN SEMUA IDENTITAS LAIN}

Gagasan-gagasan dasar tentang kewarganegaraan dalam tradisi republikan dapat ditelusuri sejak era Yunani kuno yang memuat tentang pelayanan publik, kebajikan warganegara, patriotisme, dan kehendak bersama, yang menjawab permasalahan relasi antara negara dan warganegara. Dan terakhir gagasan ini menguat kembali setelah ditenggelamkan oleh tradisi liberal dengan kritikannya terhadap tradisi liberal yang terlalu mengecilkan peran individu warganegara menjadi semata-mata atom-atom dan pemilik pasif hak-hak. Pada masa ini dikembangkan dua prinsip utama yakni kolektifitas dan keterlibatan aktif warganegara sebagai solusi alternatif atas konsep kewarganegaraan liberal. ${ }^{8}$

Dalam konsepsi republik sipil, warganegara-warganegara membentuk Negara dan Negara beroperasi sebagai satu kesatuan yang organis sifatnya. Artinya Negara bukan sekedar kumpulan individu yang terlepas satu sama lainnya. Negara dan warganegara merupakan sebuah komunitas. Untuk membentuk komunitas maka diperlukan unsure pengikat yang disebut 'pertemanan sosial'. Rosseau mengatakan bahwa 'negara (la patrie) tidak dapat eksis terus tanpa kebebasan (freedom), tidak ada kebebasan tanpa kebajikan (virtue), dan tidak ada kebajikan tanpa warganegara.' ${ }^{9}$

Menurut Miller dalam setiap perpolitikan selalu terdapat dua aspek; simbolik dan material. Menurut Miller bukanlah sebuah kebenaran yang universal bahwa kelompok dengan identitas berbeda harus mendapatkan pengakuan politik sebagai pengusung identitas tersebut. Dua tuntutan khas perpolitikan identitas yakni diberikan kesempatan membangun institusi sosial dan kebudayaan sendiri sehingga tidak terlindas ke dalam institusi sosial dan budaya kelompok yang lebih dominan, dan tuntutan untuk diinklusikan. Dua tuntutan ini menurut Miller, dapat dikarakterisasikan sebagai tuntutan untuk mendapatkan kewarganegaraan penuh dalam sebuah negara modern. Dengan demikian seorang anggota

\footnotetext{
${ }^{7}$ Isin dan Wood dalam Ibid., hal. 86.

${ }^{8}$ Nuri Suseno, Ibid., hal. 60-61.

${ }^{9}$ Seperti dikutip oleh Heater dalam bukunya, What is Citizenship?, (cambridge: Polity Press, 1999), hal.51
} 
dapat memiliki identitas ganda, menjadi anggota kelompok dan sekaligus menjadi seorang warganegara. ${ }^{10}$

Menurut Miller, memang tidak sulit untuk memahami identitas yang berbeda, tetapi menilainya apalagi memberikan dukungan merupakan dua hal yang lain. Menurutnya akan menjadi suatu permasalahan ketika muncul sekelompok warganegara yang membawa identitas tertentu yang menerapkan nilai-nilai dan praktek-praktek budaya yang dipandang bertentangan dengan nilai-nilai dasar yang dianut masyarakat luas. Demikian juga, besar kemungkinan terjadi penolakan dukungan terhadap kelompok-kelompok budaya yang menerapkan dan mempraktekkan nilai dan budaya tersebut. ${ }^{11}$

Menurut Miller, akan menjadi suatu permasalahan ketika muncul sekelompok warganegara yang membawa identitas tertentu yang menerapkan nilai-nilai dan praktekpraktek budaya yang dipandang bertentangan dengan nilai-nilai dasar yang dianut masyarakat luas. Demikian juga, besar kemungkinan terjadi penolakan dukungan terhadap kelompokkelompok budaya yang menerapkan dan mempraktekkan nilai dan budaya tersebut. ${ }^{12}$

Sebagai solusi mengatasi permasalahan diatas, maka Miller menunjukkan suatu bentuk komunitas dimana kelompok-kelompok identitas saling berhubungan dan mereka juga dapat saling memberikan dan mendapatkan pengakuan didalam komunitas bangsa dalam kesetaraan sebagai warganegara. Dalam komunitas bangsa ini menurut Miller diperlukan sebuah standar penilaian dan cara hidup yang dapat diterima oleh semua kelompok dengan identitas atau budaya yang berbeda. Dan menurutnya ini tidak berarti standar penilaian dan cara hidup dari kelompok yang dominan yang dijadikan panutan dan juga tidak berarti bahwa ia menganggap kelompok identitas tidak relevan dalam perpolitikan.

Dengan demikian dalam konsepsi Miller, maka anggota-anggota kelompok memasuki arena perpolitikan sebagai warganegara dan merepresentasikan klaim-klaim mereka bukan dalam kerangka identitas kelompok tetapi dalam kerangka prinsip dan precedents yang melekat pada praktek-praktek dalam komunitas politik yang mengekspresikan identitas nasional. ${ }^{13}$

\footnotetext{
${ }^{10}$ David Miller dalam Ibid., hal. 87.

${ }^{11}$ Ibid., hal. 88 .

${ }^{12}$ Ibid., hal. 88.

${ }^{13}$ Ibid., hal. 90.
} 


\section{KRITIK CHANTAL MOUFFE ATAS DUA TRADISI MAINSTREAM TENTANG KEWARGANEGARAAN DAN IDENTITAS}

\section{CHANTAL MOUFFE: THE UNFIXED OF ALL IDENTITIES}

Schmitt memang meletakan persamaan dalam demokrasi sebagai persamaan substansial (substantive equality) yang berbeda dengan persamaan dalam politik dan persamaan universal dalam arti kemanusiaan yang dianut paham liberalisme. Namun kritik Schmitt terhadap demokrasi liberal adalah pada keinginannya mengupayakan terjadi persamaan universal dalam politik "kewarganegaraan". Menurutnya yang termasuk warganegara adalah mereka yang dikategorikan sebagai "the demos", di luar itu bukan warganegara sehingga tidak diperlakukan setara dan ditolak kehadirannya di dalam ruang politik demokrasi. ${ }^{14}$ Kritik dari mouffe dalam buku demokrasi radikal terhadap kewarganegaran liberal maupun kewarganegaraan republican adalah diawali dari konsepsi Carl Schmitt dalam The Concept of the Political, bahwa demokrasi memerlukan homogenitas dan bila perlu menolak heterogenitas. Homogenitas, bagi Schmitt merupakan syarat terlaksananya demokrasi, karena tanpa homogenitas demokrasi tidak mungkin ada. Pada konsep ini Mouffe bersepakat dengan Schmitt, yang melihat demokrasi secara substansial, yang menempatkan setiap warganegara pada posisi yang sama dan setara untuk mengambil peran yang substansi.

Mouffe tidak sepakat terhadap Schmitt, yakni pada The Demos dan bukan warganegara, yaitu sebagai "kawan-lawan" sehingga saling menegasikan. Bagi Mouffe demokrasi adalah bukan sebagai hubungan permusuhan (enemy), bukan juga sebagai perlawanan (adversary) melainkan relasi kesahajaan, sebagai relasi "kami" dan "kita". yakni lawan bukan musuh yang perlu dihancurkan melainkan sebagai "lawan bersahaja" (friendly enemy) yang keberadaan atau eksistensinya harus diakui dan dijaga guna kelangsungan relasi demokrasi. Mouffe memang lebih menekankan partisipasi politik dibanding "consensus" demokrasi dalam liberalis atau "dominasi" dalam Civic Republican, alasan yang dikedepankan bahwa aspek-aspek partikularistik dari realitas social niscaya diabaikan. ${ }^{15}$

Mouffe dalam melihat negara multinasional menyatakan bahwa dalam konsekuensi kesetian bernegara adalah titik kesadaran untuk menumbuhkan rasa keadilan dan persamaan, bahkan kebersamaan bagi setiap warganegara baik secara individu maupun secara bagian dari kelompok warganegara. Bagi negara yang pluralis, yang biasanya tidak konsisten menegakan rasa kesetaraan dan keadilan, pemetaan aku dan bukan aku atau "kami" dan "kamu" dalam

\footnotetext{
${ }^{14}$ Op.Cit Chatal Mouffe hal. 36-45

${ }^{15}$ ibid
} 
konsep Mouffe akan menjadi daya lekat atas dinamika dan intergratif keragaman sehingga bisa menumbuhkan rasa "menyatu" dalam membangun negara-bangsa (nation state). ${ }^{16}$

Pernyataan Mouffe di atas adalah Warganegara yang minoritas bukan sesuatu yang harus dinegasikan dan dihegemoni, tetapi merupakan entitas kelompok bangsa dari bagian proses pembangunan politik nasional. Sehingga tingkat partisipasi politik yang dikedepankan mempunyai implikasi dari rasa kebersamaan dan kedirian atas segala interelasi politik kekuasaan yang diberlakukan oleh negara. Kemudian berdasar rasa kesamaan dan keadilan yang diperoleh oleh setiap individu dan kelompok warganegara negara bangsa maka persoalan kesetiaan (allegiance) akan tumbuh sebagai kepemilikan bersama atau negara menjadi ruang bersama (common space) dengan tujuan akhir adalah membangun kebaikan umum, bonum commune. Dan kaitan dengan konsepsi demokratisasi, tentang perbedaaan (multikulturalisme) yang ada dalam negara bangsa atau pada multi nasional diletakan sebagai antagonistik sebagai persaingan damai antara friend dan friend enemy. Segenap individu sebagai warganegara terikat dari rasa untuk tetap "ada" bersama sebagai satu negara-bangsa. Rasa "ada" bersama ini yang oleh Duverger diposisikan sebagai "ikatan psikologis" yan membangun "citra" kolektif dari rasa persaudaraan. ${ }^{17}$

\section{KEWARGANEGARAAN MOUFFE DALAM KONTEKS KE INDONESIAN}

Prinsip Kewarganegaraan Mengenai kewarganegaraan ini biasanya ditentukan berdasarkan salah satu dari dua prinsip, yaitu prinsip 'ius soli' atau prinsip 'ius sanguinis'. Yang dimaksud dengan 'ius soli' adalah prinsip yang mendasarkan diri pada pengertian hukum mengenai tanah kelahiran, sedangkan 'ius sanguinis' mendasarkan diri pada prinsip hubungan darah. Indonesia sendiri menganut prinsip 'ius sanguinis'. Berdasarkan prinsip 'ius soli', seseorang yang dilahirkan di dalam wilayah hukum suatu negara, secara hukum dianggap memiliki status kewarganegaraan dari negara tempat kelahirannya itu. Negara Amerika Serikat dan kebanyakan negara di Eropa termasuk menganut prinsip kewarganegaraan berdasarkan kelahiran ini, sehingga siapa saja yang dilahirkan di negaranegara tersebut, secara otomatis diakui sebagai warga negara. Oleh karena itu, sering terjadi warganegara Indonesia yang sedang bermukim di negara-negara di luar negeri, misalnya karena sedang mengikuti pendidikan dan sebagainya, melahirkan anak, maka status anaknya diakui oleh Pemerintah Amerika Serikat sebagai warga negara Amerika Serikat. Padahal kedua orangtuanya berkewarganegaraan Indonesia. Dalam zaman keterbukaan seperti

\footnotetext{
${ }^{16} \mathrm{ibid}$

${ }^{17}$ op.cit. Boni Hargens 68
} 
sekarang ini, kita menyaksikan banyak sekali penduduk suatu negara yang berpergian keluar negeri, baik karena direncanakan dengan sengaja ataupun tidak, dapat saja melahirkan anakanak di luar negeri. Bahkan dapat pula terjadi, karena alasan pelayanan medis yang lebih baik, orang sengaja melahirkan anak di rumah sakit di luar negeri yang dapat lebih menjamin kesehatan dalam proses persalinan. Dalam hal, negara tempat asal sesorang dengan negara tempat ia melahirkan atau dilahirkan menganut sistem kewarganegaraan yang sama, tentu tidak akan menimbulkan persoalan. Akan tetapi, apabila kedua negara yang bersangkutan memiliki sistem yang berbeda, maka dapat terjadi keadaan yang menyebabkan seseorang 6 menyandang status dwi-kewarganegaraan (double citizenship) atau sebaliknya malah menjadi tidak berkewarganegaraan sama sekali (stateless).

Berkaitan dengan negara multinasional seperti yang menjadi kekayaan Indonesia, Mouffe sepertinya dapat dijadikan solusi atas heterogenitas dan pluralitas bangsa ini, tidak saja kelompok mayoritas tetapi dihuni oleh banyaknya ragam kelompok minoritas. Brkaitan dengan kondisi Inodnesia yang dihimpun oleh banyaknya kelompok minoritas, Saya setuju dengan pendapat kewarganegaraan Mouffe bahwa warganegara yang minoritas bukan sesuatu yang harus dinegasikan dan dihegemoni, tetapi merupakan entitas kelompok bangsa dari bagian proses pembangunan politik nasional. Warganegara tidak saja dituntut dalam tingkat parsitisapasi politiknya tetapi juga harus dikedepankan implikasi dari rasa kebersamaan dan kemandirian atas segala interelasi politik kekuasaan yang diberlakukan oleh negara.

Menurut saya, pendapat Mouffe merujuk tidak saja warnaganegara " bebas untuk" tetapi juga “ bebas dari” artinya identitas yang melekat pada warganegara bukan semata-mata identitas yang dihegemoni oleh negara seperti identitas nasionalisme tetapi juga identitas dari bawaan individu itu sendiri. Oleh sebab itu saya sepekat bahwa dalam negara demokrasi yang multikultural seperti Indonesia identitas kewarganegaraan bukanlah "satu identitas di antara banyak identitas" atau "satu identitas yang dominan yang menekankan semua identitas lainya" melainkan adalah floatring signifier, artinya Indonesia sebagai negara demokrasi dan memiliki multikultural identitas warganegara mengandung ambiguitas radikal didalamnya dan bersifat terbuka, dimana ambiguitas radikal memandang bahwa demokrasi maupun identitas yang ada bukanlah konsep yang pasti tetapi konsep yang dibentuk oleh konteks tertentu dan bersifat terbuka dimaksudkan pada menerima segala pemaknaan dan reartikulasi. Sederhannanya, dalam demokrasi dan identitas menerima nilai-nilai plural, demokrasi bukan konsep universal, melainkan dibentuk oleh nilai-nilai lokal dan particular seperti agama, sosial, budaya dan politik serta ekonomi. 
Melihat multikulturalnya bangsa Indonesia, merujuk pada pendapat Mouffe bahwa diperlukan kesetiuan setriap warganegara, dimana pada setiap individu ada rasa " solidaritas sosial dalam makna kolektivitas. Artinya, setiap warganegara di Indonesia harus tetap menjunjung solidaritas sosial sebagai bangsa nasional Indonesia dibawah Bhineka Tunggal Ika dan menjunjungnya sebagai rasa memiliki bersama.

\section{DAFTAR PUSTAKA}

Boni Hargens, 2006, Demokrasi Radikal : Memahami Paradox Demokrasi Modern Dalam Perspektif Postmarxis-Ostmodernis Ernesto Laclau Dan Chantal Moufee. Lkis : Yogyakarta Mouffe Chantal, 2000, The Democratic Paradox, VERSO: London, New York

Nuri Suseno, Kewarganegaraan : Tafsir, Tradisi, Dan Isu-Isu Kontemporer. Depok : Departemen Ilmu Politik FISIP UI, 2010 